DEPARTMENT of ENERGY U.S.A.

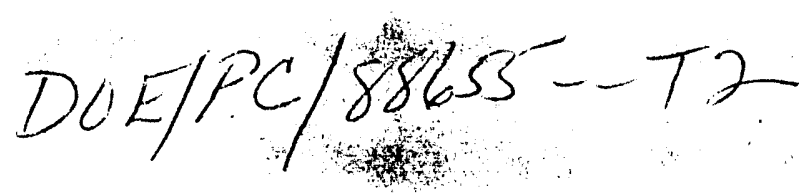

is

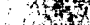

MINISTRY 1 ENIRRY and INIRASTRUCTURE ISPAR

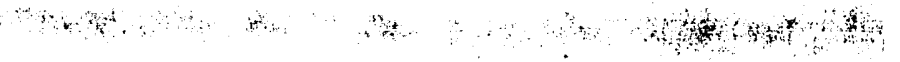

$\mathrm{DOE} / \mathrm{PC} / 88655--\mathrm{T} 2$

SCIENTIFIC REPORT

DE93 006138

\title{
COMBUSTION OF PULVERIEAD COAL IN COUNTER-CURRENT FLOW
}

\author{
FINAL REPORT
}

(Grant No. DE-FG22-89PC88655)

\section{Principal Investigators: Y.M. Timnat and Y. Goldman Feculty of Aerospace Engineering Technion - Irrael Institute of Technology Haifa 32000, Irraed}

\section{DISCLAIMER}

This report was prepared as an account of work sponsored by an agency of the United States Government. Neither the United States Government nor any agency thereof, nor any of their employees, makes any warranty, express or implied, or assumes any legal liability or responsibility for the accuracy, completeness, or usefulness of any information, apparatus, product, or process disclosed, or represents that its use would not infringe privately owned rights. Reference herein to any specific commercial product, process, or service by trade name, trademark, manufacturer, or otherwise does not necessarily constitute or imply its endorsement, recommendation, or favoring by the United States Government or any agency thereof. The views and opinions of authors expressed herein do not necessarily state or reflect those of the United st wes Government or any agency thereof. 
DEPARTMENT of ENERGY

U.S.A.
MINISTRY of ENERGY and INFRASTRUCTURE ISRAEL

\author{
SCIENTIFIC REPORT
}

COMBUSTION OF PULVERIZED COAL IN COUNTER-CURRENT FLOW

(Grant No. DE-FG22-89PC88655)

Principal Investigators: Y.M. Timnat and Y. Goldman Faculty of Aerospace Engineering

Technion - Israel Institute of Technology

Haifa 32000, Israel

Report period from December 7, 1988 to April 30, 1991. 
COMBUSTION OF PULVERIZED COAL IN COUNTER-CURRENT FLOW

Y. Goldman and Y.M. Timnat

Faculty of Aerospace Engineering

Technion - Israel Institute of Technology

Haifa 32000, Israel.

\section{INTRODUCTION}

One of the main areas of development and research in intensification of coal combustion involves buming of pulverized fuel (PF). In this process the overall interaction surface between the reactants (oxygen and coal particles) is about two orders of magnitude bigger than in other methods (stokers, grates, fluidized beds, etc.). As concluded in a recent Guide to Industrial Coal and Ash Handling (Guide, 1988) PF systems of firing are suitable for a wide range of applications from power generation boilers to gas turbines. The advantages compared to other systems will result in increase in importance of future PF applications.

Improvement of combustion intensity in PF combustors can be attained by two basic techniques. The cyclone furnace (Holmes-Smith et al. 1961) is based on the use of tangential injection of air containing pulverized coal, so swirling motion of the combustion products is created in the combustion chamber, with intensive chemical reaction occurring in the boundary layers adjacent to the walls. Recently, attempts were made to reduce $\mathrm{NO}_{x}$ formation (Cioffi, 1989) and to model mathematically the detailed flow and mixing processes in tangentially fired furnaces (Benesch and Kremer, 1984). The three-dimensional calculations supply valuable predictions concerning these processes but do not include combustion and heat transfer effects. However such effects can also be calculated (see, for example, Zhou et al. 1986, Boyd and Kent, 1986).

The second technique of PF combustion intensification is the entrained bed or Koppers-Totzek coal system (Dainton, 1979), which uses opposed jets of pulverized coal that impinge on the center of the combustion chamber, with an exhaust port in its upper section. The high relative velocities between the coal 
particles and the gaseous phase in the impingement area provide correct conditions for diffusion and convetion at the particle surface and, together with the high temperature, result in : : burning and gasification. The major drawback of this technique is that it does not allow to control the mution of coal particles after leaving the impingement region, so that some may leave the combustion area before completion of the buming process. Studies of alternative improved combustors based on the opposed flow principle have been reported by Goldberg and Essenhigh (1978) and Goldman et al. (1981). More recently, Hazanov et al. (1985) and Greenberg et al. (1989) described an opposed flow combustor in which secondary and tertiary air are supplied in the final stage of combustion.

Their configuration is very promising as it enables improved control of the combustion process. The results indicate that aerodynamic stability of combustion within such a chamber may be achieved in an optimal fashion by appropriate adjustment of the flow and the thermal conditions prevalent in the primary, secondary and tertiary jets. There is little doubt that this configuration will be suitable for high pressure applications and GT cycles.

Experimental studies of some elements, used in this technique are reported by Stankevich et al. (1983) (inflowing prinary jets coalescing near a combustor centerline and forming a single jet), Syred et al. (1987) and Pröbstle and Wenz (1988) (flow properties in a swirl driven combustion chamber).

In this report we describe the results obtained with two prototypes of pulverized coal combustors operating in counter-current flow, one at atmospheric pressure, the other at higher pressure and compare them to the predictions of a theoretical-numerical model, we have developed. The first prototype treats a vertical configuration, eight times larger than the one treated before (Hazanov et al. 1985), while in the second a horizontal arrangement with a smaller volume is studied. Attention was focused on particle trajectories, burn-out, angle of injection, ash separation by rotational motion, effects of initial particle size 
and temperature, impingement velocity and the effect of gravity. Main development activity was directed to achieving stable and reliable coal burning in the combustors. 


\section{COAL ANALYSIS}

Coal used in the combustors came from two sources: For several tests in the first year's operation of the atmospheric vertically arranged combustion we used a bituminous coal del:vered from Pittsburgh \#8 Seam Bailey Mine, Greene County, Pennsylvania, USA. For smaller pressurized type combustor we used a bituminous coal, delivered from Hadera Power Plant, Israel. The coal analysis report is as follows:

Proximate Analysis

$\begin{array}{ll}\text { U.S.A. } & \text { Israel - Hadera } \\ \text { Coal } & \text { Power Plant Coal }\end{array}$

Volatile Matter

Fixed Carbon

Ash

Sulfur

Heating Value

Heating Value

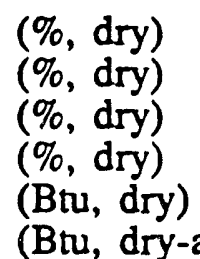

(Btu, dry-ash free)
36.73

57.08

6.19

1.22

14143

15076
26.8

$6 \pm 1$

1.35

$15000 \pm 100$

\section{Mineral Analysis}

$\begin{array}{lrc}\mathrm{Ai203} & 28.27 & 24.8 \\ \mathrm{Si02} & 51.22 & 40.0 \\ \mathrm{Ti02} & 1.12 & - \\ \mathrm{Fe} 203 & 13.43 & 13.1 \\ \mathrm{CaO} & 1.83 & 6.5 \\ \mathrm{Na} 20 & 0.42 & 0.4 \\ \mathrm{Mg0} & 0.75 & - \\ \mathrm{K} 20 & 1.79 & 0.5 \\ \mathrm{P} 205 & 0.58 & - \\ \mathrm{S} 03 & 1.36 & -\end{array}$

Ash Fusion Temperature $(\stackrel{\circ}{C})$

Oxidizing atmosphere IDT

\section{Coal Particles Size Distribution}

See Fig. 1 for Rosin-Rammler type of distribution: $R(x)=100 \exp \left(-b \cdot x^{n}\right)$, where $R(x)$ is the percentage of particles that remains on a sieve having a mean aperture of $x$ micrometers. The constant $b$ is equal to 0.0006 for the U.S. coal and 0.0026 for the Hadera coal. The constant $n$ is 1.31 and 1.3 , respectively. 


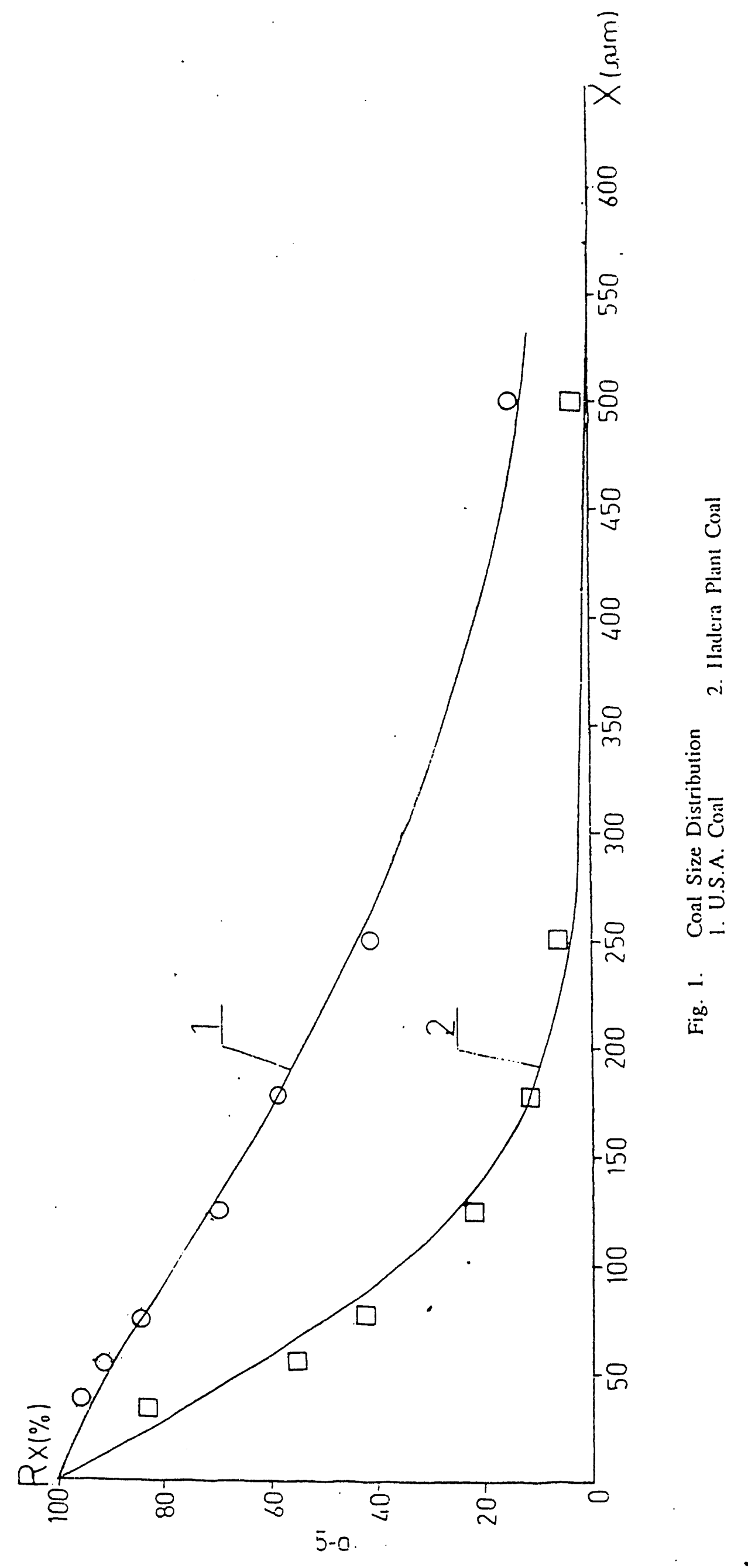




\section{TECHNICAL DATA OF THE COMBUSTORS}

First prototype for atmos- Second prototype for spheric pressure operation high pressure operation

Inner dimensions:

Diameter

Length

Exit diameter

Volume

Arrangement:

Fuel consumption:

Air consumption:

Total

Primary

Secondary

Tertiary

Combustion chamber temperature:

Fuel burn out:

Big particles

(bigger than $120 \mu \mathrm{m}$ )

Small particles

NO concentration at

combustor exit:

$\mathrm{SO}_{2}$ concentration at

combustor exit:

Volumetric burning intensity: $\quad \approx 2 \cdot 10^{6} \frac{\mathrm{Kcal}}{\mathrm{h} \mathrm{r} \cdot \mathrm{m}^{3}}$
$70 \div 85 \%$

$85+98 \%$

$300+400 \mathrm{ppm}$

by weight

$300+350 \mathrm{ppm}$
$420 \mathrm{~mm}$

$800 \mathrm{~mm}$

$220 \mathrm{~mm}$

$0.11 \mathrm{~m}^{3}$

horizontal

$70 \mathrm{~kg} / \mathrm{h}$

$460+580 \mathrm{~m}^{3} / \mathrm{h}$

$\approx 25 \%$

$\simeq 65 \%$

$\simeq 10 \%$

$1500+1650^{\circ} \mathrm{K}$
$82+97 \%$

$300+400 \mathrm{ppm}$

by weight

$300+350 \mathrm{ppm}$

$\approx 3 \cdot 10^{6} \frac{\mathrm{Kca} 1}{\mathrm{~h} \mathrm{r} \cdot \mathrm{m}^{3}}$

Details of the combustors construction and components arrangement are presented in the Appendix to the report. 


\section{MATHEMATICAL MODEL AND COMPUTATIONAL PROCEDURE}

The mathematical model takes into account only primary and secondary jets, although tertiary air was also introduced; it uses axisymmetric domain for the combustion chamber, excluding the region of the primary hot jets, in which volatilization of the coal particles occurs. Thus a mixture of coal particles and hot gases (air, carbon dioxide, carbon monoxide and hydrogen) enters the solution domain from one side, while a steady jet of air is inserted on the other. The entire combustor is assumed to be in a steady state. Drag forces are exerted on the particles due to the gaseous environment and the differences in velocity, but the converse effect is neglected since the volume occupied by the particles is small. Two-way heat transfer is, however, accounted for.

The gas phase equations were solved iteratively to convergence, assuming no particles present. The coal particles equations were then integrated, exploiting current velocity and temperature values of the environment. Temperature corrections to the gas phase were made using a split-operator method (Greenberg and Presser, 1981). The relation convergence criterion was $10^{-3}$.

\section{ATMOSPHERIC PRESSURE WORK}

The atmospheric pressure combustor is shown in Fig. 2. One can observe the entrances of the primary air, carrying the coal (2), which are at a $45^{\circ}$ angle, found to be optimal (in a previous study), the secondary air entrance on the top (3), the tertiary air (4) is introduced on two sides and the ash is collected in a hopper (6).

The computed results of the coal particle trajectories, which disregard, as mentioned, the contribution of the tertiary air, are illustrated in Fig. 3 for five initial diameters, between 50 and 500 micrometers. The initial temperature assumed for the jet is $1700 \mathrm{k}$ with a velocity of $13.9 \mathrm{~m} / \mathrm{s}$, while the secondary air enters at a temperature of $350 \mathrm{~K}$ and a velocity of $5 \mathrm{~m} / \mathrm{s}$. Qualitatively the 


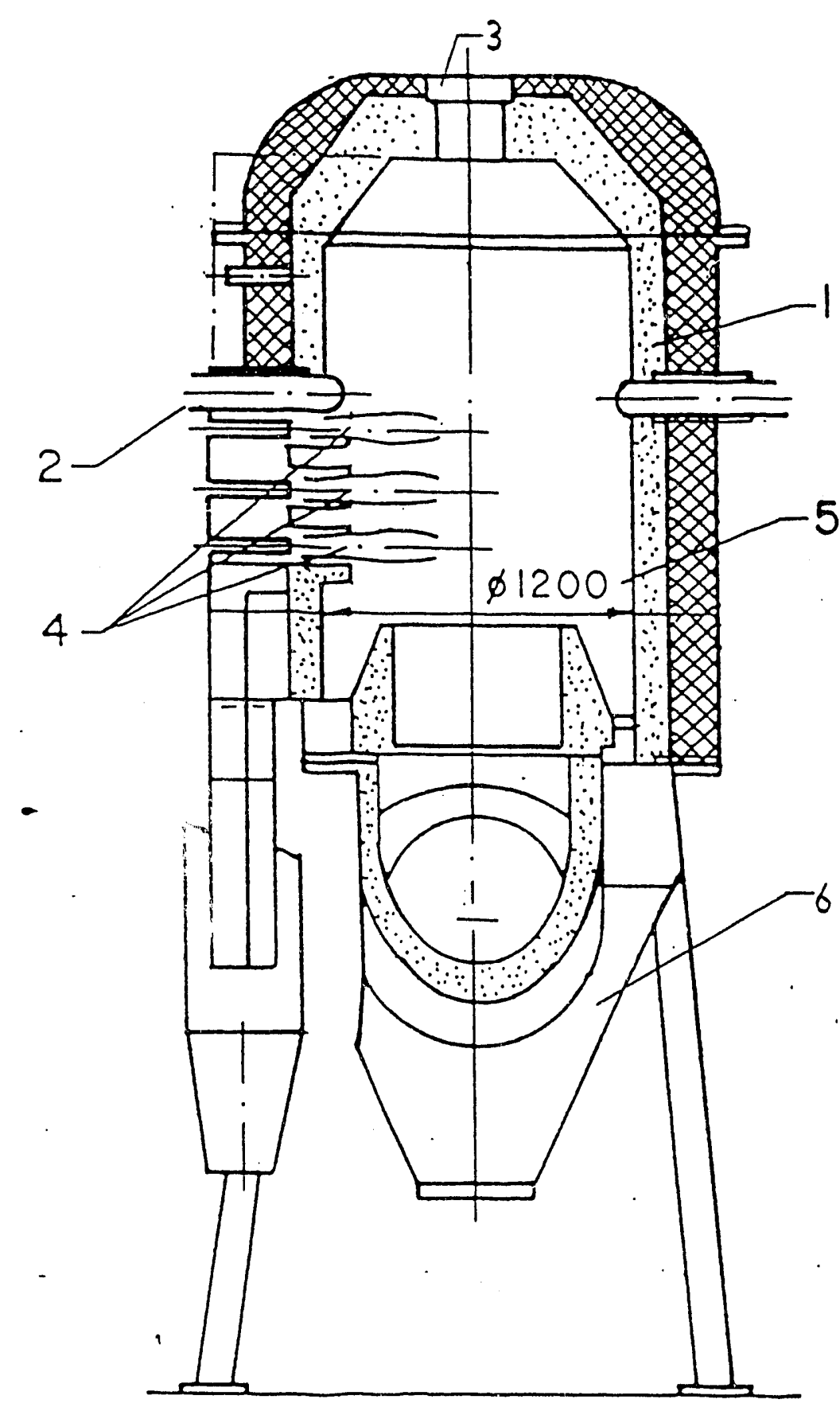

Fig. 2. Atmospheric Pressure Combustor

1. Combustion Chamber

2. Primary Air and Coal

4. Tertiary Air

3. Secondary Air

5. Outlet

6. Ash Hopper 


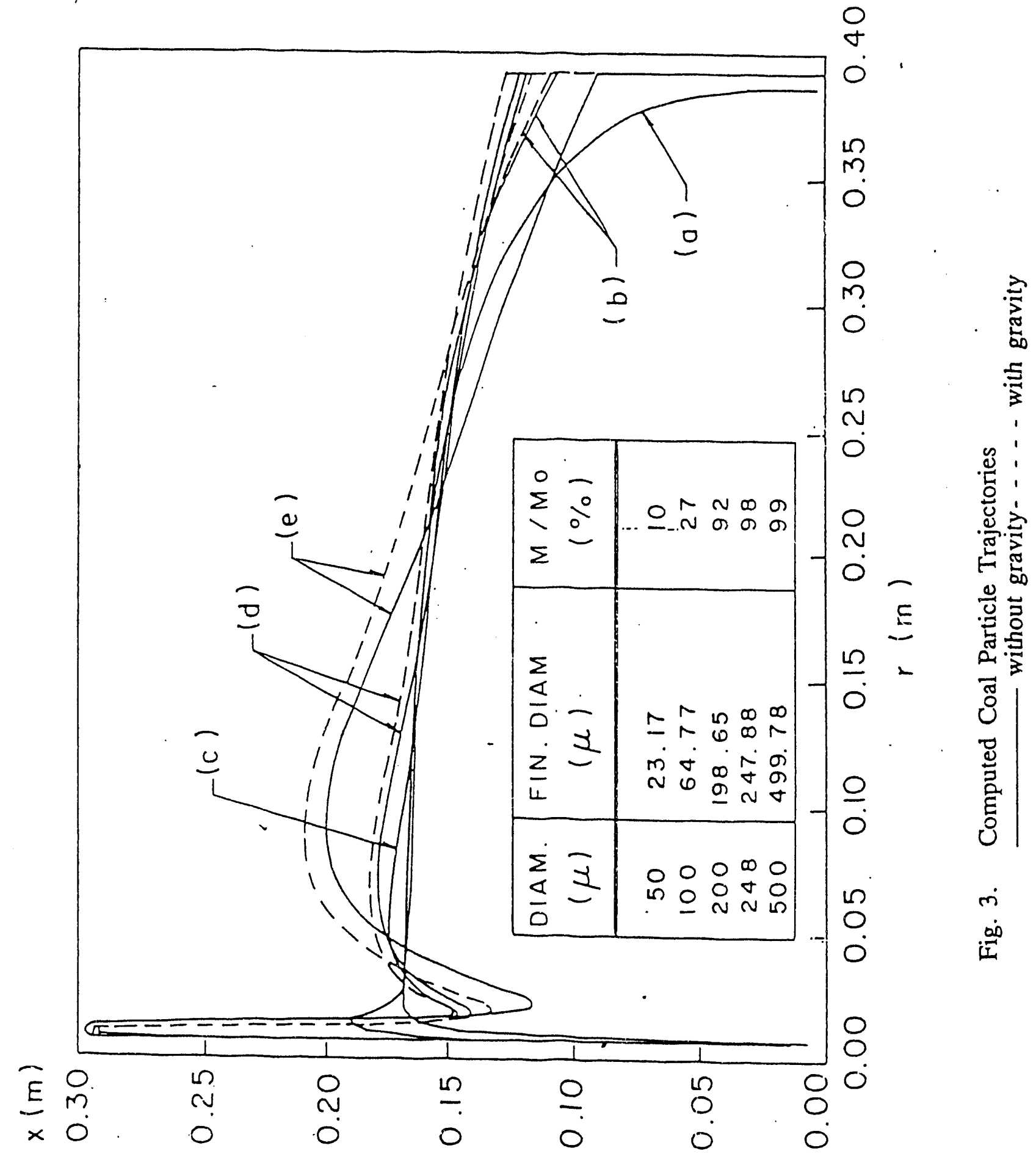


behavior is similar to that observed by Hazanov et al. (1985). The larger the initial particles, the greater their initial momentum, with the consequence that their movement beyond the stagnation point brings them in close proximity to the secondary air entrance. However, despite the longer trajectories the larger particles appear to survive the chamber, presumably due to their initially lower temperature that is certainly not enhanced by entering the colder region produced by the secondary air. The oscillatory trajectory resulting from stabilization on the environment's streamlines is similar to previous observations (Wendt et al. 1986). Interestingly, the effect of gravity is almost negligible even for the $500 \mu \mathrm{m}$ particles. It can be explained by very short exposure time $(0.1+0.2 \mathrm{sec})$ of the particles within the intensive burning region.

In order to compare these results with the experiments one must remember that the two primary jets carrying the pulverized coal impinge on each other in the center of the chamber, forming a single merged jet (see Hazanov et al. 1985 and a direct photograph of the jets in Fig. 4). This moves upwards and collides with the secondary air stream moving in the opposite direction from the top. A stagnation plane is thus created, at which the primary flow turns down towards the chamber exit, while inertial forces cause the coal particles to continue their upward movement. The are decelerated by drag, which together with the acceleration effect of the secondary flow in the opposite direction results in size separation. The experimental findings are compared with computed data in Fig. 5; the depth of penetration of the coal particles beyond the stagnation point into the secondary air stream is plotted against the particle diameter ( $D_{\min }$ and S.M.D.). The agreement is good. It is worth noting that microscopic observation of the particles captured in the air counter flow indicate the presence of a certain quantity of small particles even deep into the secondary stream. This may be caused either by fragmentation of bigger particles close to 


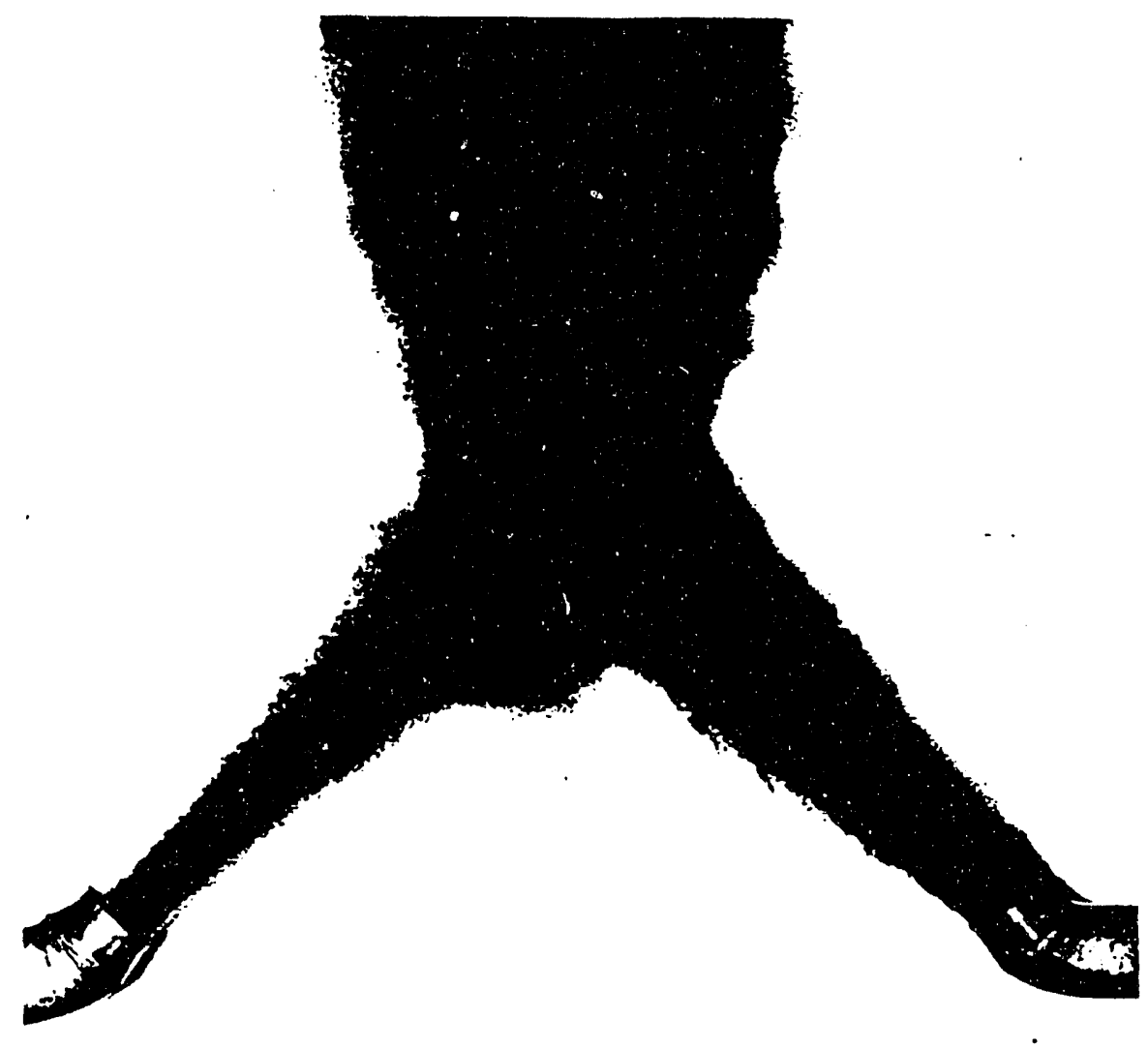

Fig. 4. Photo of Coal Jets Impinging at $45^{\circ}$ 


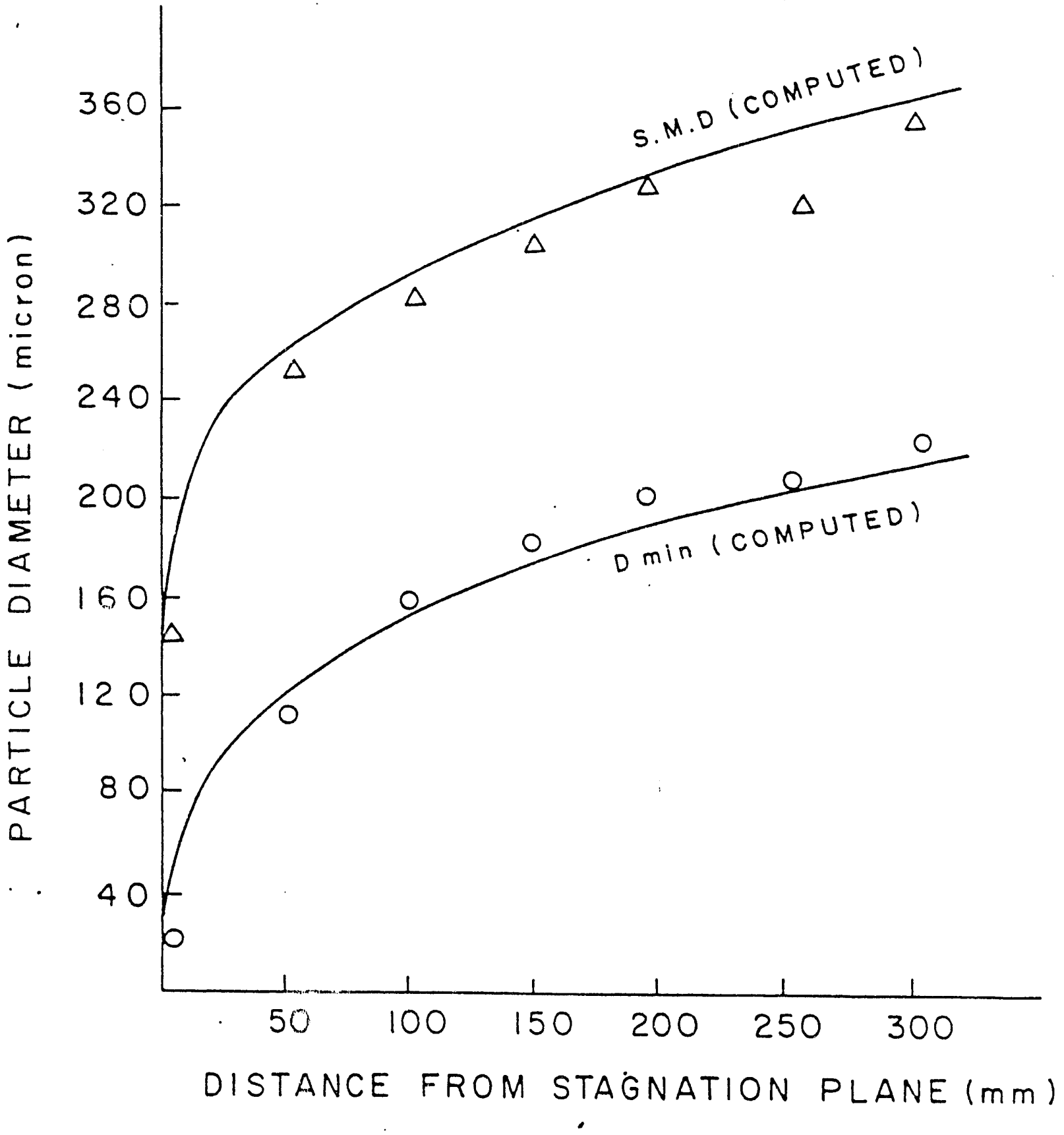

Fis. 5. Depth of Coal Particle Penetration into Secondary Flow Region.
Experiment vs. theory 
the monitoring instruments or by scavenging of smaller particles by larger ones. Figure 6 compares the calculated and measured extent of total reaction for typical conditions, showing qualitative agreement. In Fig. 7 the experimental data for the extent of total reaction (volatiles and char) at different locations in the combustor are depicted. At the combustor exit (curve 3) all particles below 200 microns were completely burnt. Bigger particles up to $1.1 \mathrm{~mm}$ do not have enough time for complete combustion and leave the combustor with $24+30 \%$ of unburnt carbon.

Results of the tertiary air introduction on the particle velocity and on centrifugal ash separation are presented in Fig. 8. Intensive rotational flow in the lower section of the combustor is aimed at creating centrifugal forces in the aerosol, similar to a conventional cyclone separator. The higher tertiary air flow rate resulted in higher tangential velocity at the chamber wall. As a result of the strong rotational movement in the gas volume, a significant difference in particulate matter distribution was achieved. It was found that ash concentration close to the wall was $3+4$ times higher than in the central core of the flow. The main quantitative results are: fuel consumption - 300 $\mathrm{kg} / \mathrm{h}$; combustion chamber temperature - $1500+1600 \mathrm{~K}$; chamber volume $0.70 \mathrm{~m}^{3}$; maximal ash separation achieved - $70 \%$; fuel bum out - $80+85 \%$ for big particles and about $100 \%$ for small particles (less than 120 microns), $\mathrm{NO}_{x}$ concentration in combustions products $-300+400 \mathrm{ppm}, \mathrm{SO}_{2}$ concentration $-300+350 \mathrm{ppm}$.

\section{PRESSURIZED COMBUSTOR}

The pressurized combustor, shown in Fig. 9, uses a BBC VTR-320 turbocompressor to raise the pressure and a pilot gas burner for ignition. Liquid fuel supplied through the secondary air inlet preheats the chamber insulation (high grade aluminum concrete and alumina fiberfax) to the temperature of stable coal buming. Significant changes of the flow regime at 


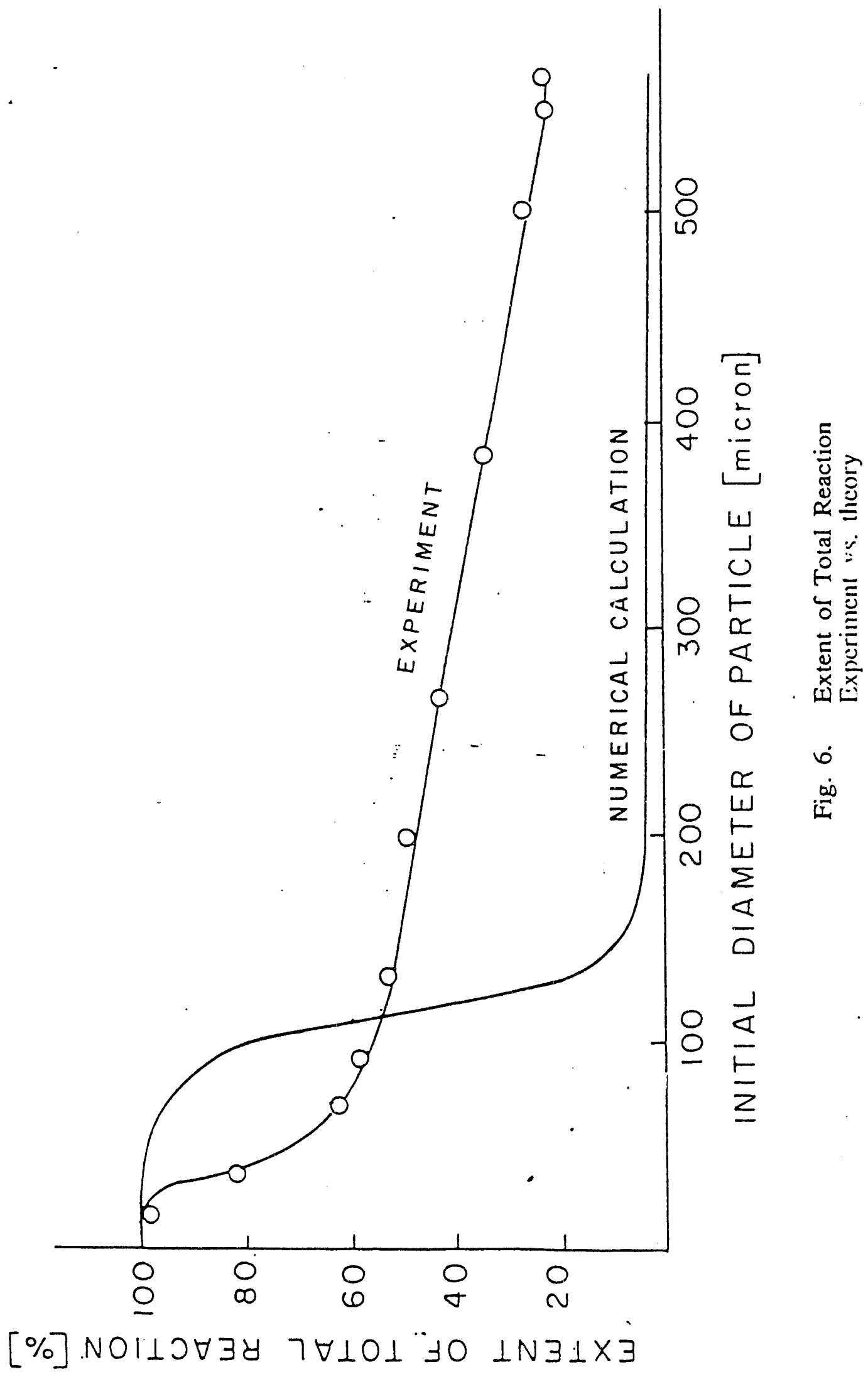




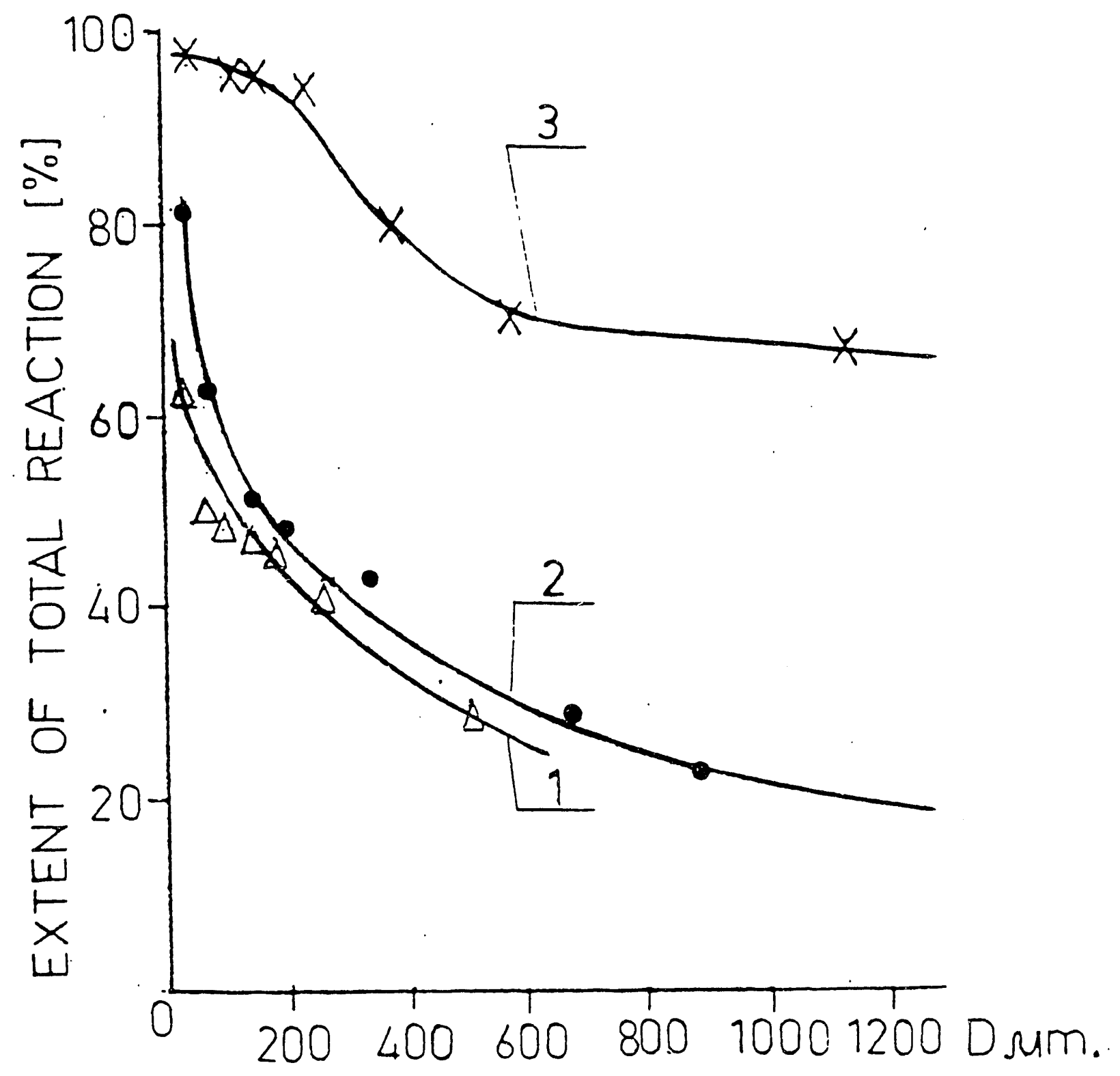

Fig. 7. Extent of Total Reaction. Experimental Data.

1. Impingement point. 2. Mid-point. 3. Combustor Exit 

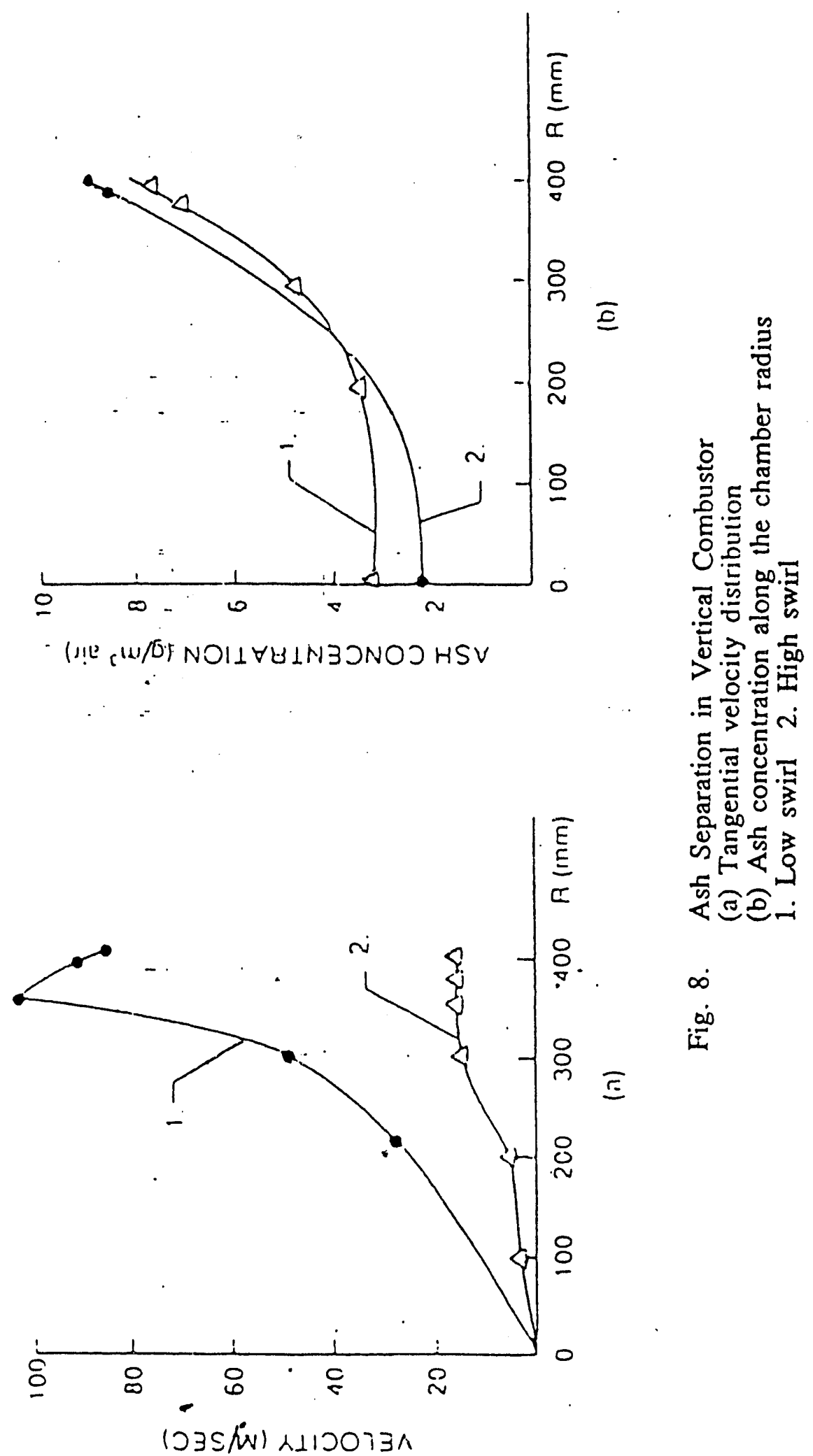


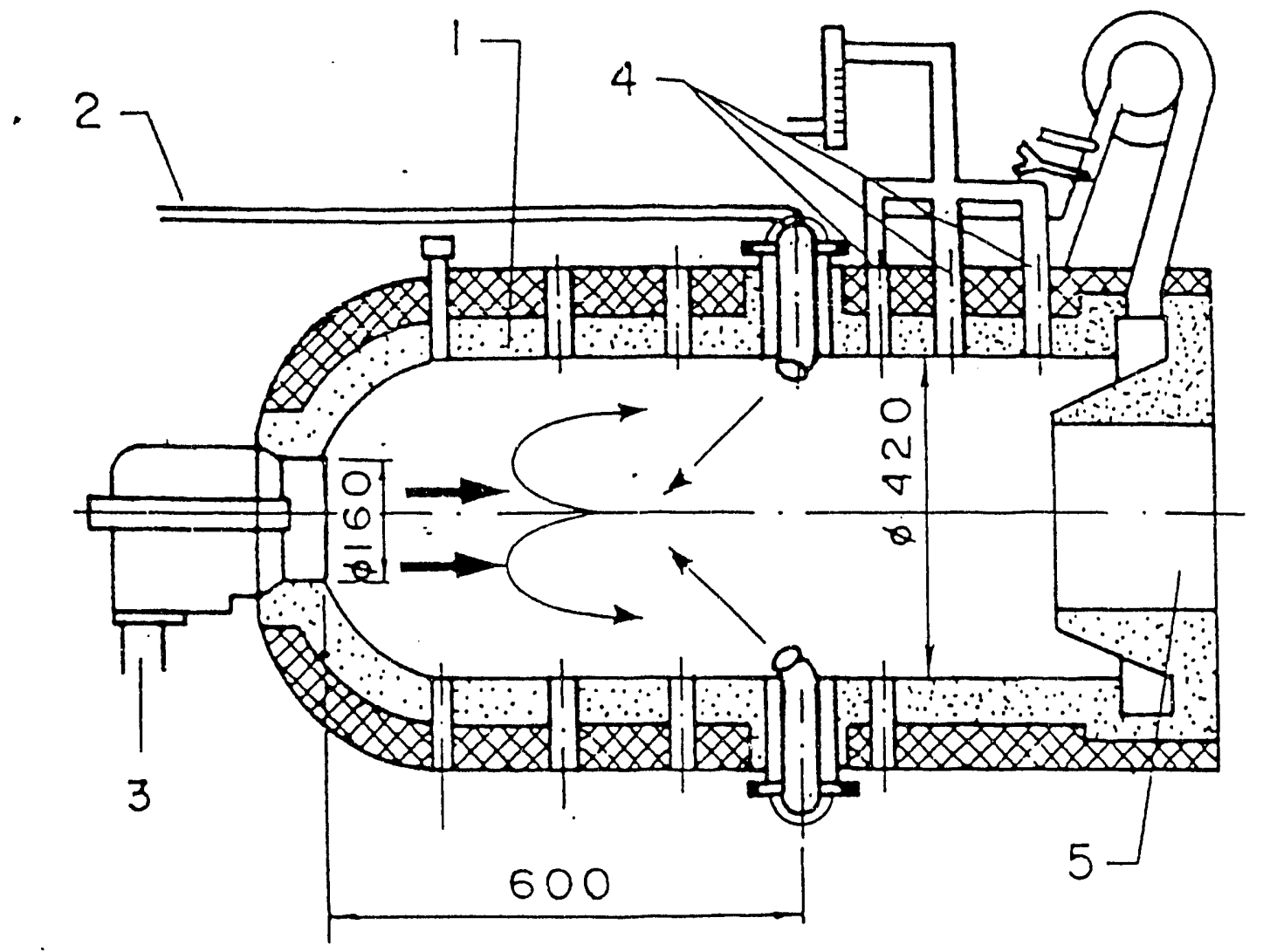

Fig. 9. Pressurized Combustor 
high pressure (when keeping the fuel consumption constant) and the limitations of the compressor restricted the combustion pressure range to 2 atmospheres. Other relevant input data are: primary jet velocity $16.4 \mathrm{~m} / \mathrm{s}$, flow rate .028 $\mathrm{kg} / \mathrm{s}$, surrounding temperature $1500 \mathrm{~K}$, combined jet velocity $7-8 \mathrm{~m} / \mathrm{s}$ and jet radius $.056 \mathrm{~m}$.

Figure 10 shows the influence of pressure on the particle temperature in the primary jets. Within the devolatilization zone between the primary air nozzle and the impingement point, corresponding to a length of about $30 \mathrm{~cm}$, the temperature rises gradually for atmospheric pressure and steeply for the higher pressure. The increase of oxygen and carbon dioxide partial pressure, together with the decrease in jet velocity are responsible for the difference. As expected higher temperatures correspond to small particles.

In general these higher temperatures accomplished the volatilization in the high pressure combustor, as shown in Fig. 11. At low pressure only a very small percentage of volatiles left coal particles bigger than 70 microns. For small particles intensive volatile matter reaction occurred even at low pressure.

The burning processes in the combustion zone are somewhat faster at high pressure, as can be seen by comparing Fig. 10a with Fig. 10b. However, higher velocity and lower density in case a) results in deeper particle penetration in the secondary jet, as can be ascertained by comparing the path from $x=0.12$ to $x=0.24$ and back.

Comparison between atmospheric and pressurized combustion chamber operation is presented in Fig. 13. Coal particle samples were monitored from different points of the combustor along the particles travel path from the moment they enter the chamber. The distance till they collide at the chamber axis is about $0.29 \mathrm{~m}$ and the leaving point is at about $1.45 \mathrm{~m}$ (measured along the average trajectory).

The total reaction extent is defined as: 


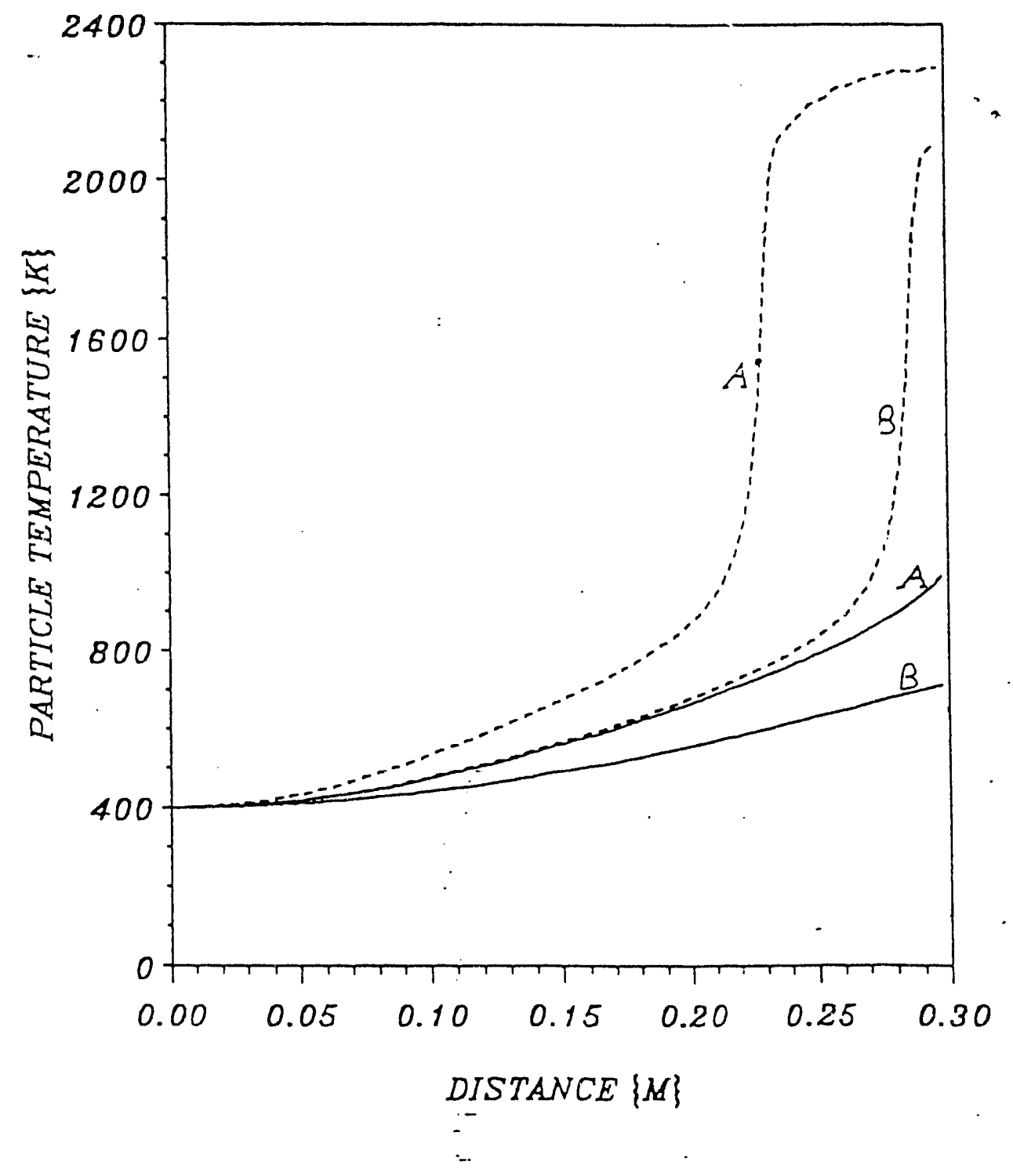

Fig. 10. Particle Temperature in Primary Jet

$$
\begin{array}{ll}
1 \mathrm{~atm} & \cdots .2 \mathrm{~atm} \\
\mathrm{~A}-70 \mu \mathrm{m} & \mathrm{B}-100 \mu \mathrm{m}
\end{array}
$$




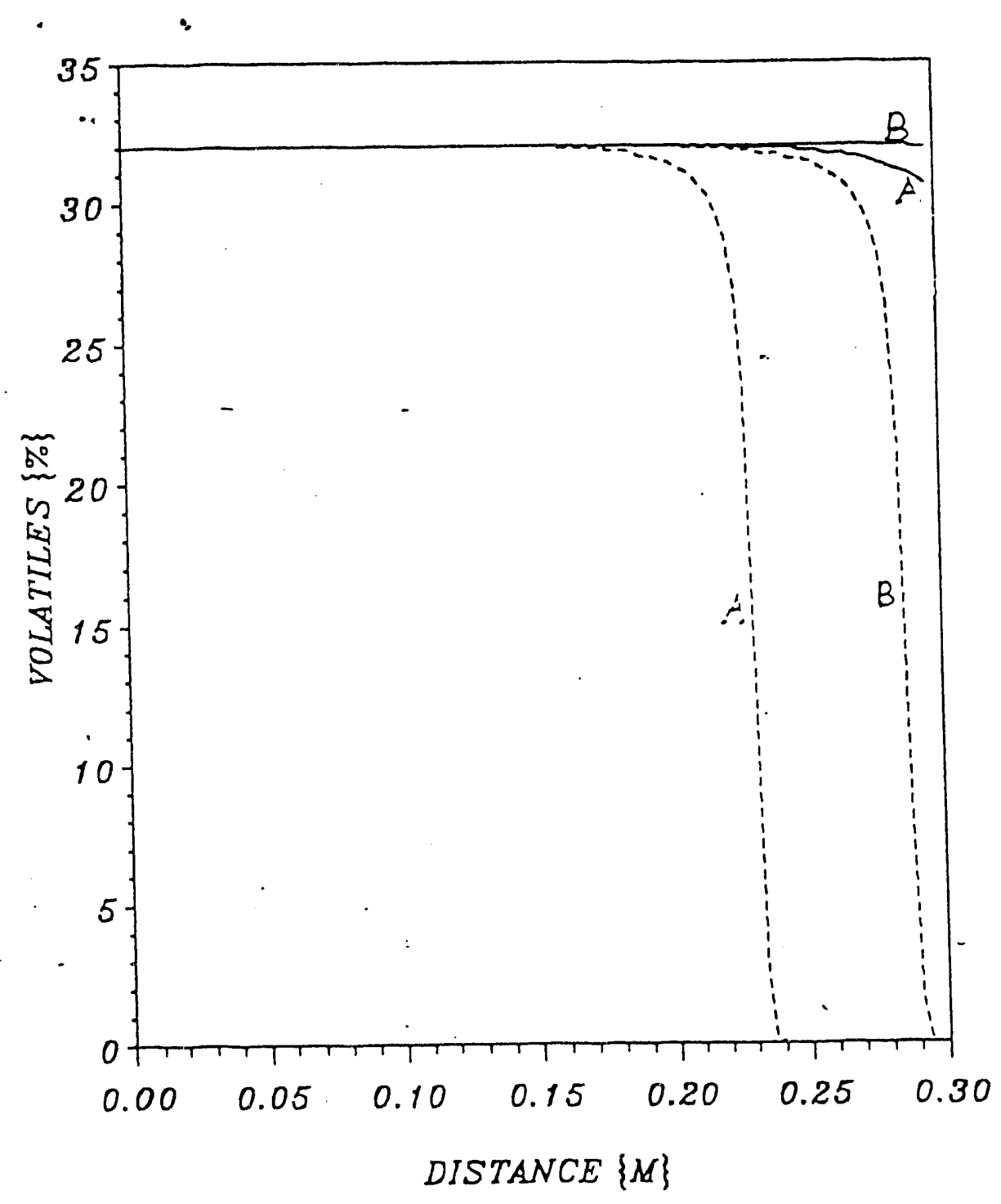

Fig. 11. \% Volatiles in Primary Jet

$$
\begin{array}{ll}
1 \mathrm{~atm} & \cdots .2 \mathrm{~atm} \\
\mathrm{~A}-70 \mu \mathrm{m} & \mathrm{B}-100 \mu \mathrm{m}
\end{array}
$$



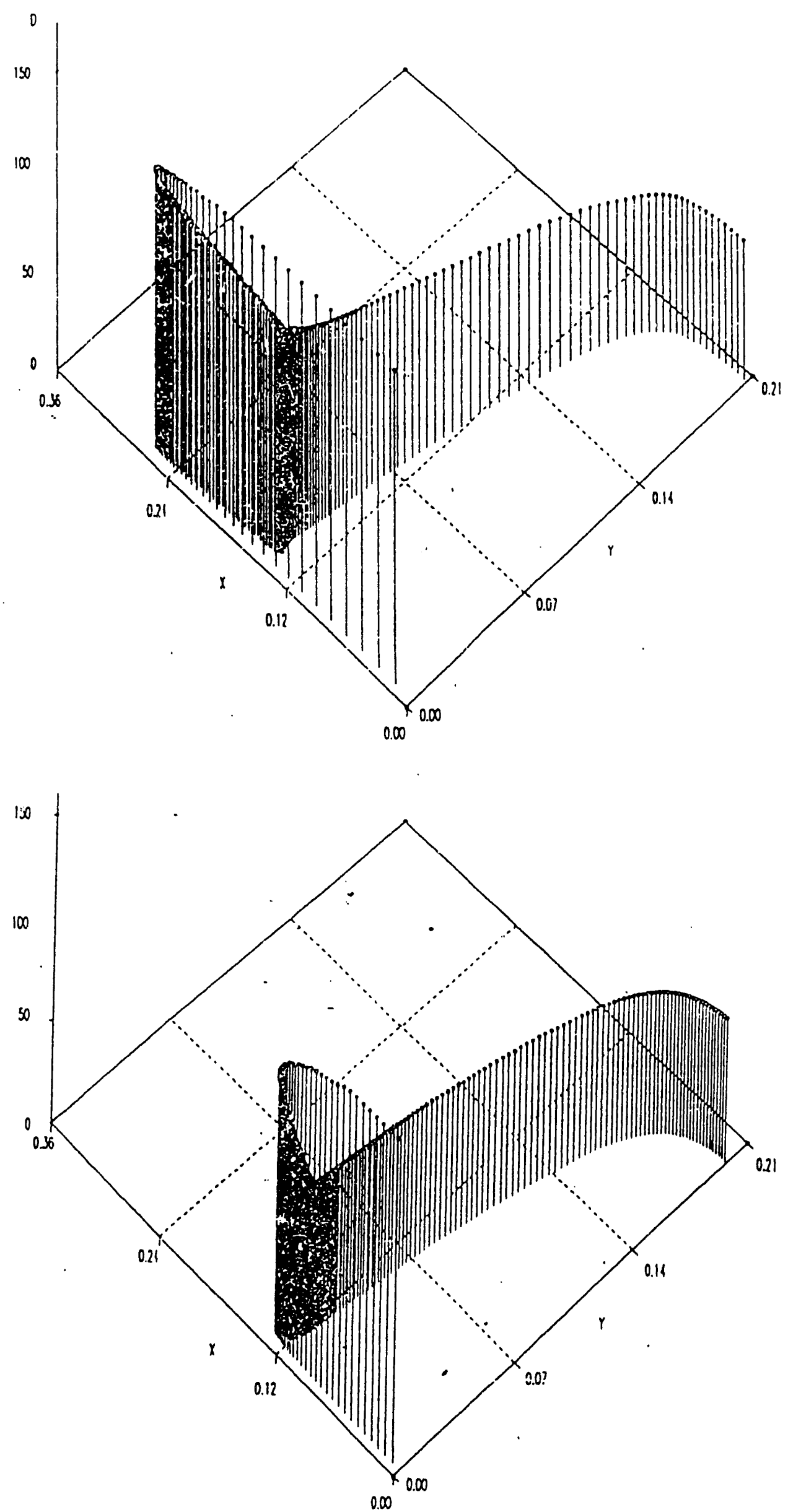

Fig. 12. Diameter Variation Along Trajectory

Initial diameter $150 \mu \mathrm{m}$ - final diameter $69.6 \mu \mathrm{m}$

$\begin{array}{ll}\text { (a) } 1 \mathrm{~atm} & \text { (b) } 2 \mathrm{~atm}\end{array}$

$10-c$ 


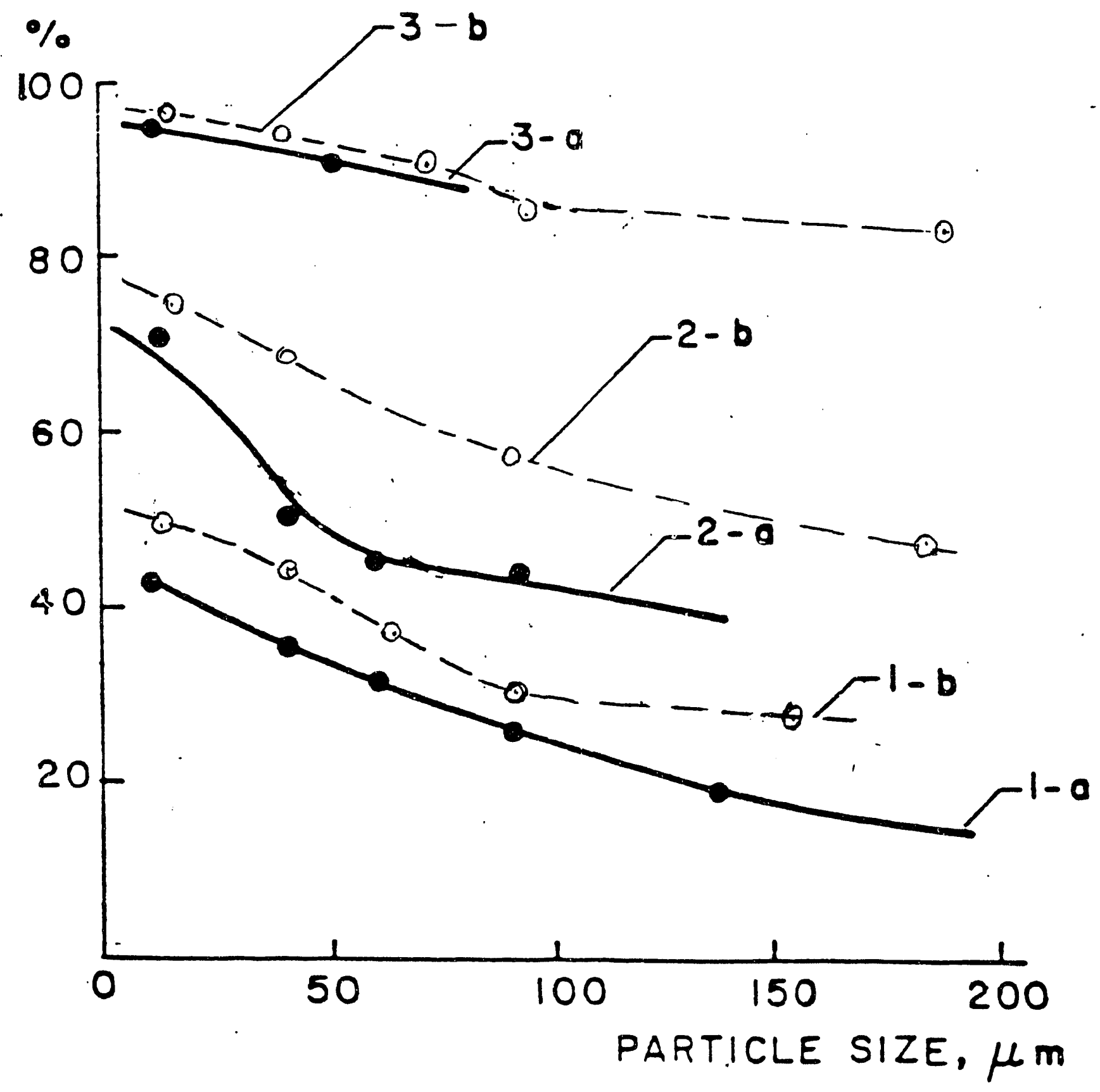

Fig. 13. Coal Reaction Extent as a Function of Particle Size (S.M.D.) At a distance from coal inlet: $1-29 \mathrm{~cm}, 2-54 \mathrm{~cm}, 3-145 \mathrm{~cm}$. Full symbols, a - atmospheric pressure; open symbols, $\mathrm{b}$ - pressurized combustor (2 psi). 


$$
100 \cdot\left(a_{2}-a_{1}\right) /\left(100-a_{1}\right) \cdot a_{2} .
$$

Here $a_{1}$ and $a_{2}$ are ash concentration in a particular fraction of the initial pulverized coal and of the sample, respectively.

Sauter mean diameter (S.M.D.) are calculated from known Rosin-Rammler distribution coefficients within each size group.

One can observe that some intensification of the burning and volatilization process takes place in the pressurized combustor. It is especially expressed at the initial part and less noticeable at the end of the burning process. Sufficient decrease of the reaction extend is found for bigger particles that are in good agreement with the computational data.

\section{SUMMARY}

Improving the pulverized coal combustion and ash separation process can be achieved in aerodynamically stabilized combustors. The results indicate that stability of combustion within such configurations can be obtained in an optimal fashion by appropriate adjustment of the flow and thermal conditions prevalent in primary, secondary and tertiary jets. Staging the air supply and applying counter-current flow of the combustion products enhances significantly the burning intensity of pulverized coal. Some increase in the coal combustion intensity can be obtained in the pressurized combustion area at pressure of up to 2 at.

A hitherto unperformed theoretical/numerical investigation of a counter flow burning of coal particles has been performed. Experimental evidence validating predictions for a vertical and horizontal pressurized combustor give weight to the capability of the model. In addition, upgrading of the combustor dimensions provides favorable burming conditions for larger particles.

Reliable burning process in two prototypes of the combustor creates expectation that this system will be suitable for small and average size boilers and furnaces as well as for gas turbine in combined cycle power generators. 


\section{ACKNOWLEDGEMENT}

This work was supported by the U.S. Department of Energy, D.F. Gyorke monitor, to whom we wish to express our gratitude. 


\section{REFERENCES}

Benesch, W. and Kremer, H., "Mathematical Modelling of Fluid Flow and Mixing Tangentially Fired Fumaces", Twentieth Symposium (International) on Combustion, The Combustion Institute, 549-557, 1984.

Boyd, R.K. and Kent, J.H., "Three-Dimensional Furnace Computer Modelling", Twenty-First Symposium (International) on Combustion, The Combusion Institute, 265-274, 1986.

Cioffi, P., "100 Demonstration of Coal Reburn in Cyclone Boilers", Modern Power Systems, 69-73, Feb. 1989.

Dainton, A.D., in Coal and Modern Processing, Academic Press, New York, 1979.

Goldberg, P.M. and Essenhigh, R.H., "Coal Combustion in a Jet-Mix Stirred Reactor", Seventeenth Symposium (Internationa!) on Combustion, The Combustion Institute, 145-154, 1978.

Goldman, Y., Shahaf, M. and Timnat, Y.M., "Flames with Impinging Jets", Israel J. Techn, 19, 188-192, 1981.

Greenberg, J.B. and Gold.san, Y., "Volatilization and Buming of Pulverized Coal, with Radiation Heat Transfer Effects, in a Counter Flow Combustor", Combustion Sci. and Tech., 64, 1-17, 1989.

Greenberg, J.B. and Presser, C., "A Fully Automatic Method for Predicting Intemal Reacting Flows", J. Comp. Phys. 40, 361-375, 1981.

Guide to Industrial Coal and Ash Handling, British Material Handling Board, Elsevier Applied Science, London and New York.

Hazanov, Z., Goldman, Y. and Timnat, Y.M., "Opposed Flow Combustion of Pulverized Coal", Comb. Mlame, 61, 119-130, 1985.

Holmes-Smith, E., Lister, J. and Liddell, P.V., "The New High Pressure Cyclone Boiler at Wilton", J. Inst. Fuel, 37. 307, 1961.

Pröbstle, G. and Wenz, W., "Velocity Measurements in a Swirl Driven Pulverized Coal Combustion Chamber", Cornbustion and Flame, 72, 193-203, 1988.

Stankevich, J.O.A., Steward, C.S. and Mattsson, A.C.J., "Toroidal Flow CoalFired MHD Combustor Design Study and Tests", AIAA 21st Aerospace Science Meeting, AlAA-83-0467, 1983.

Syred, N., Claypole, T.C. and MacGregor, S.A., "Cyclone Combustors", in C.J. Lawn (Ed.), Principles of Combustion Engineering for Boilers, Academic Press, London, 1988. See also: Biffin, M., Morgan, D.J. and Syred, N., "Multi-Fuel Cyclone Combustors with Integrated Ash Removal", 1st European Conf. on Industrial Furnaces and Boilers, Lisbon, Portugal, 1988.

Wendt, J.O.L., Kram, B.M., Masteller, M.M. and McCasslin, B.D., "Coal Pyrolysis in Flat, Laminar, Opposea Jet Combustion, Configurations", Twenty-First Symposium (Internationai) on Combustion, The Combustion Institute, 419-426, 1986. 
Zhou, L., Lin, W., Zhang, J. and Wang, J., "Numerical Modelling of ThreeDimensional Flow Field and Two-Dimensional Coal Combustion in a Cylindrical Combustor of Co-Flow Jets with Large Velocity Difference", Twenty-First Symposium (International) on Combustion, The Combustion Institute, 257-264, 1986. 
APPENDIX 

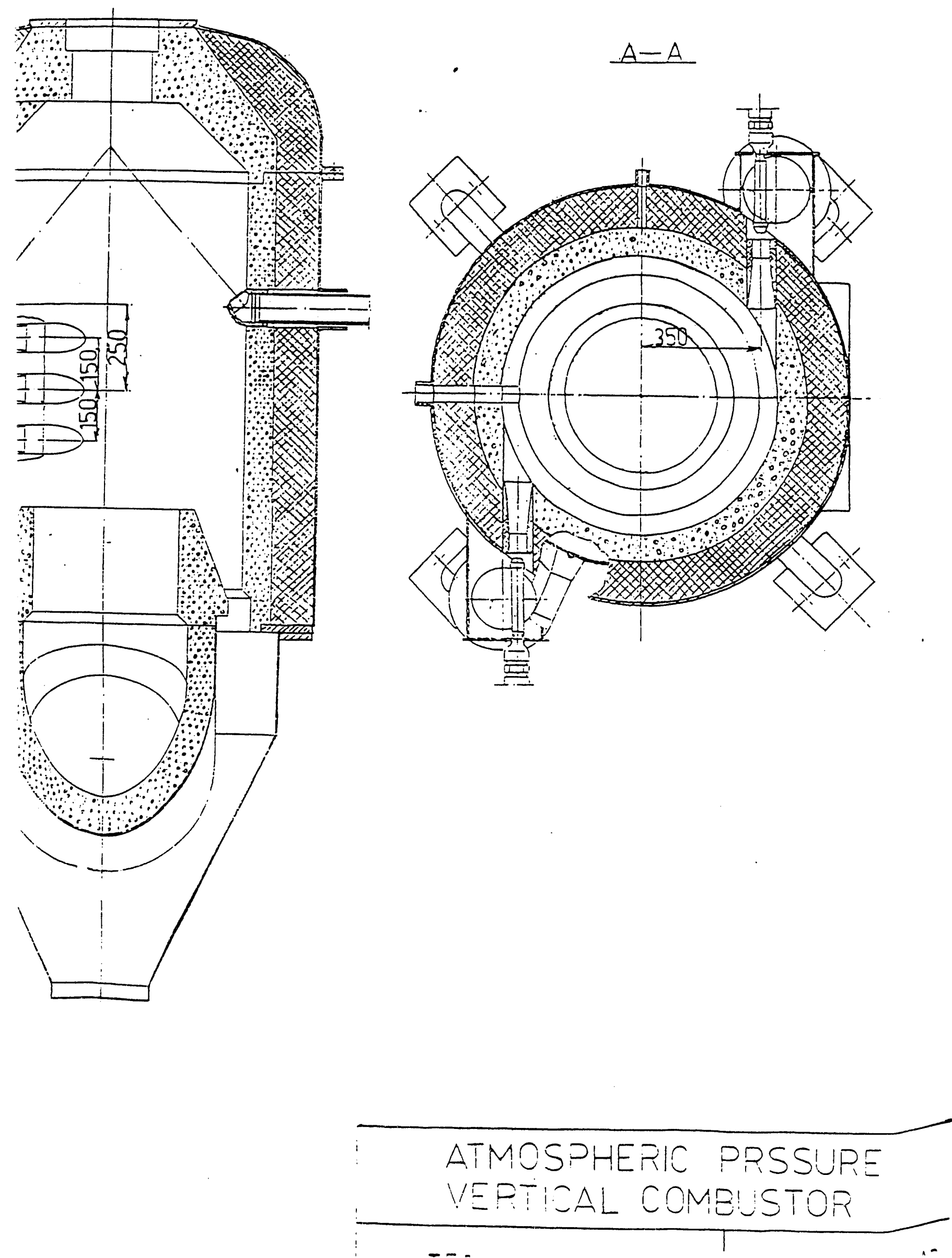

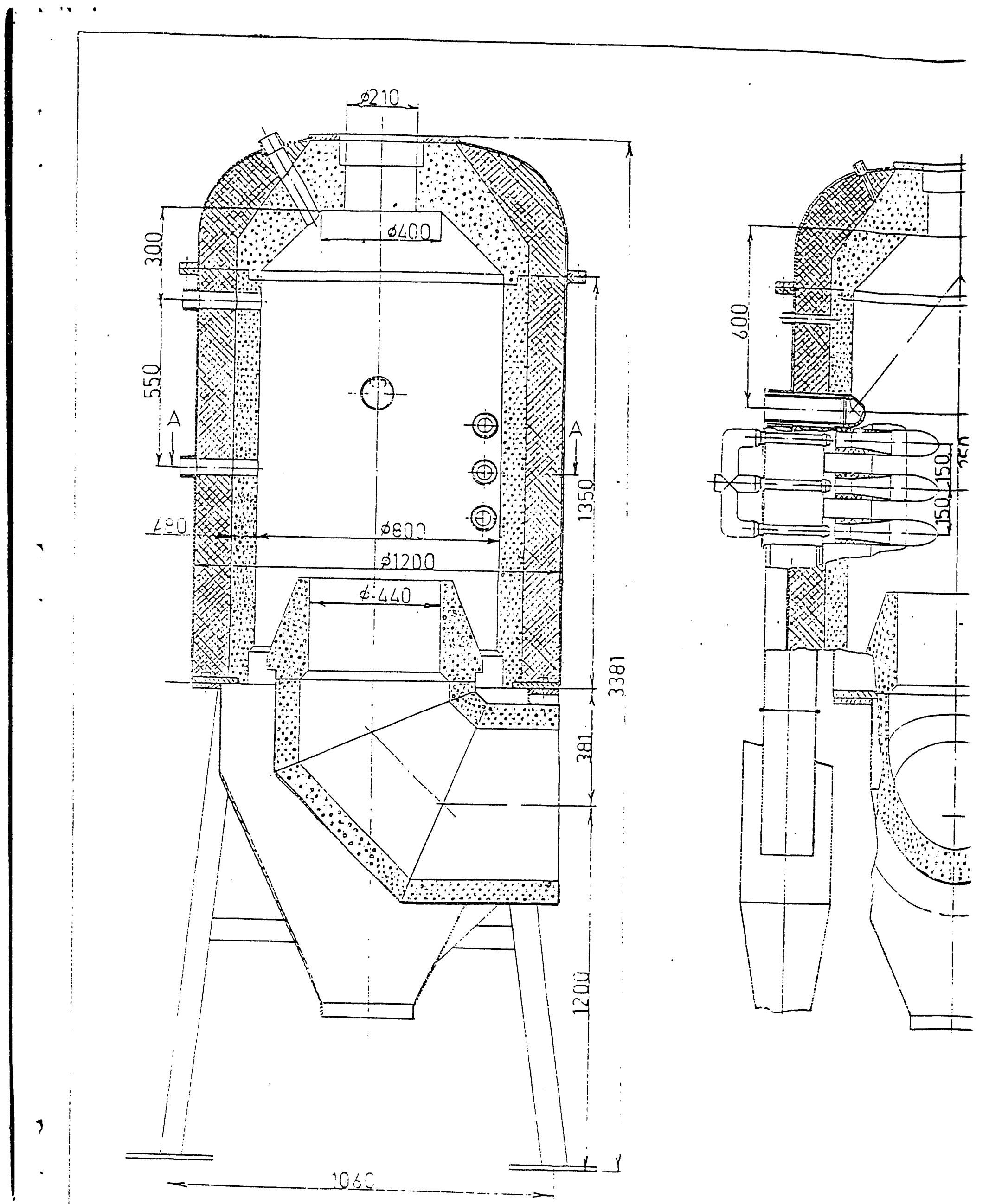


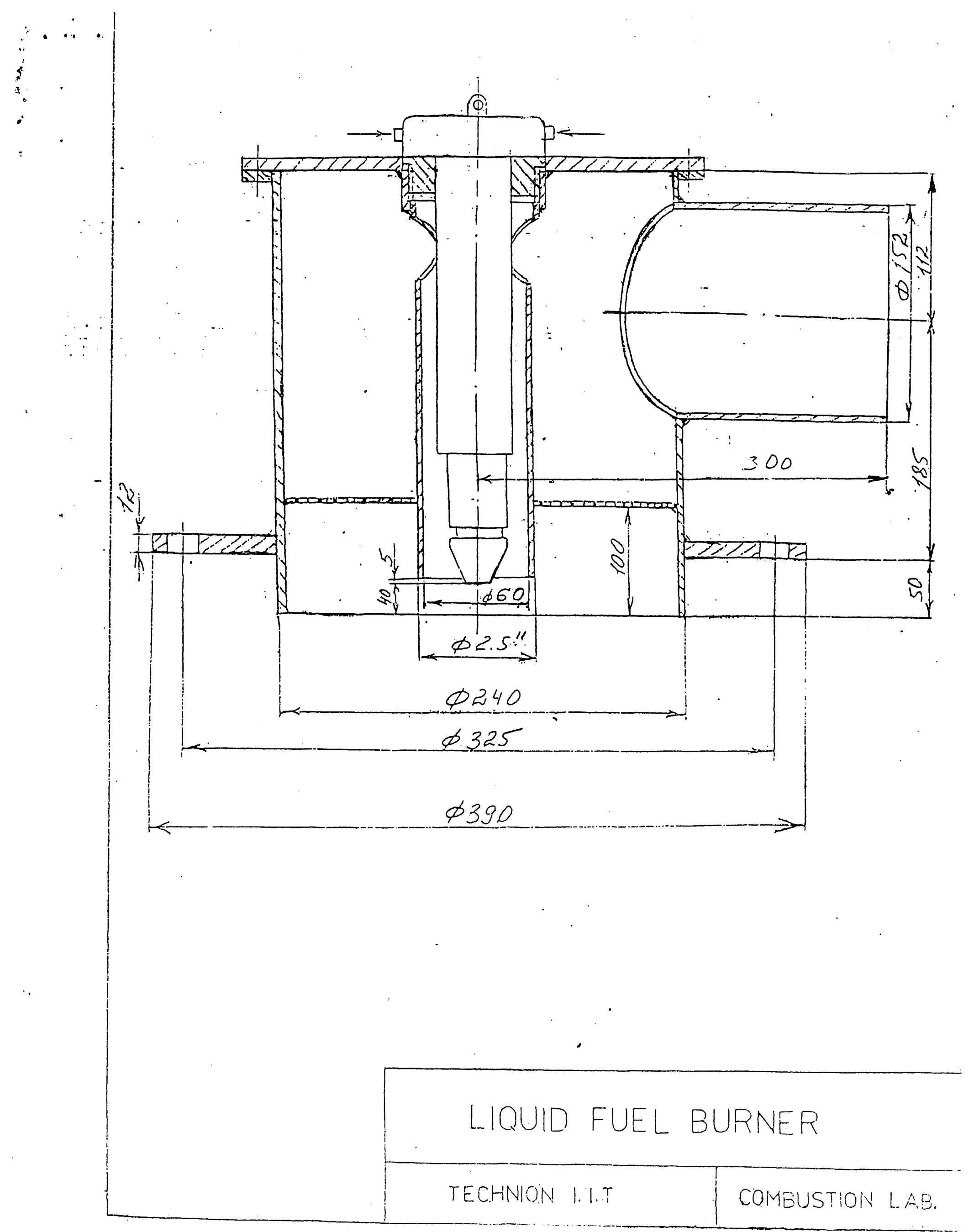




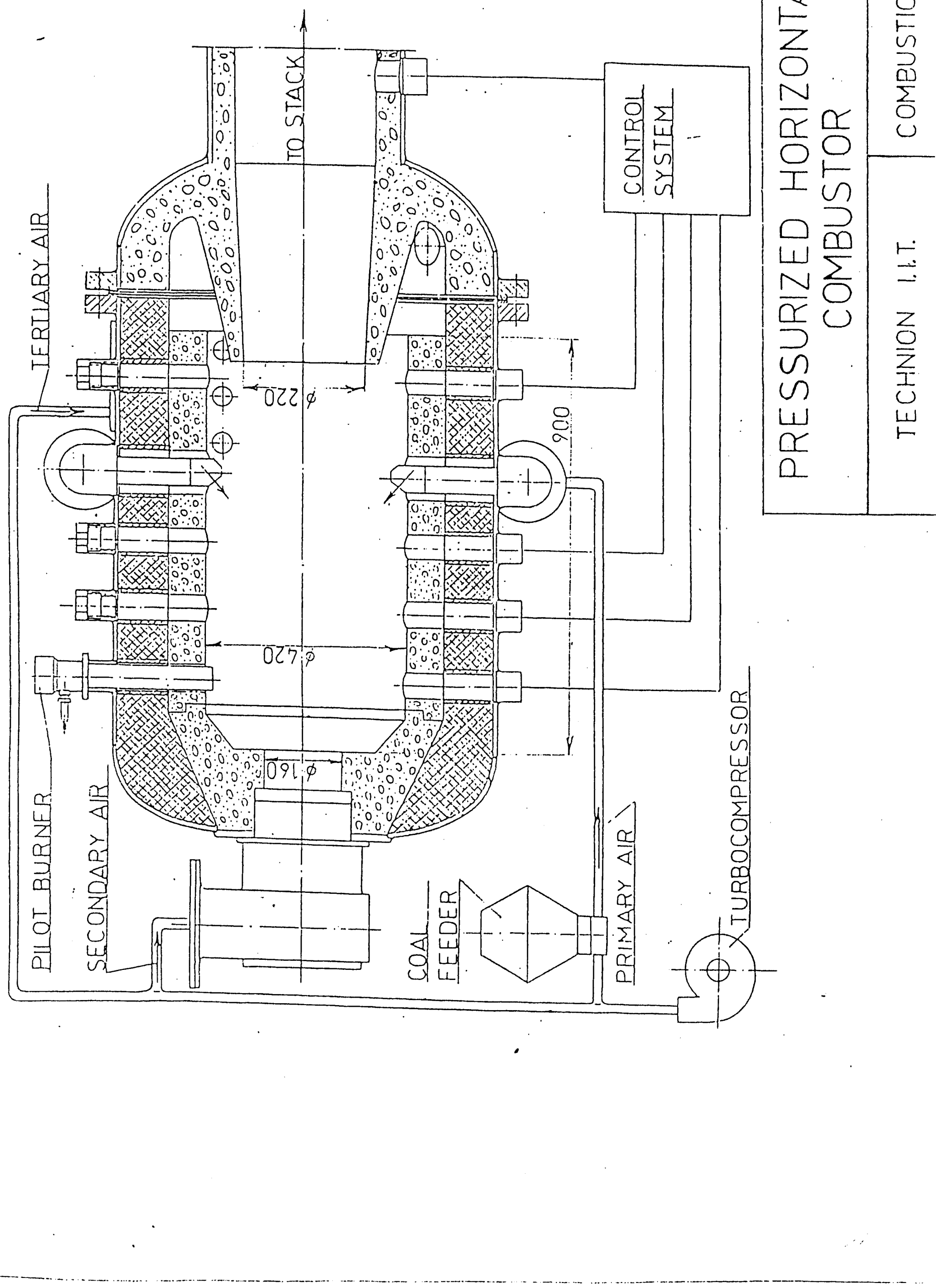




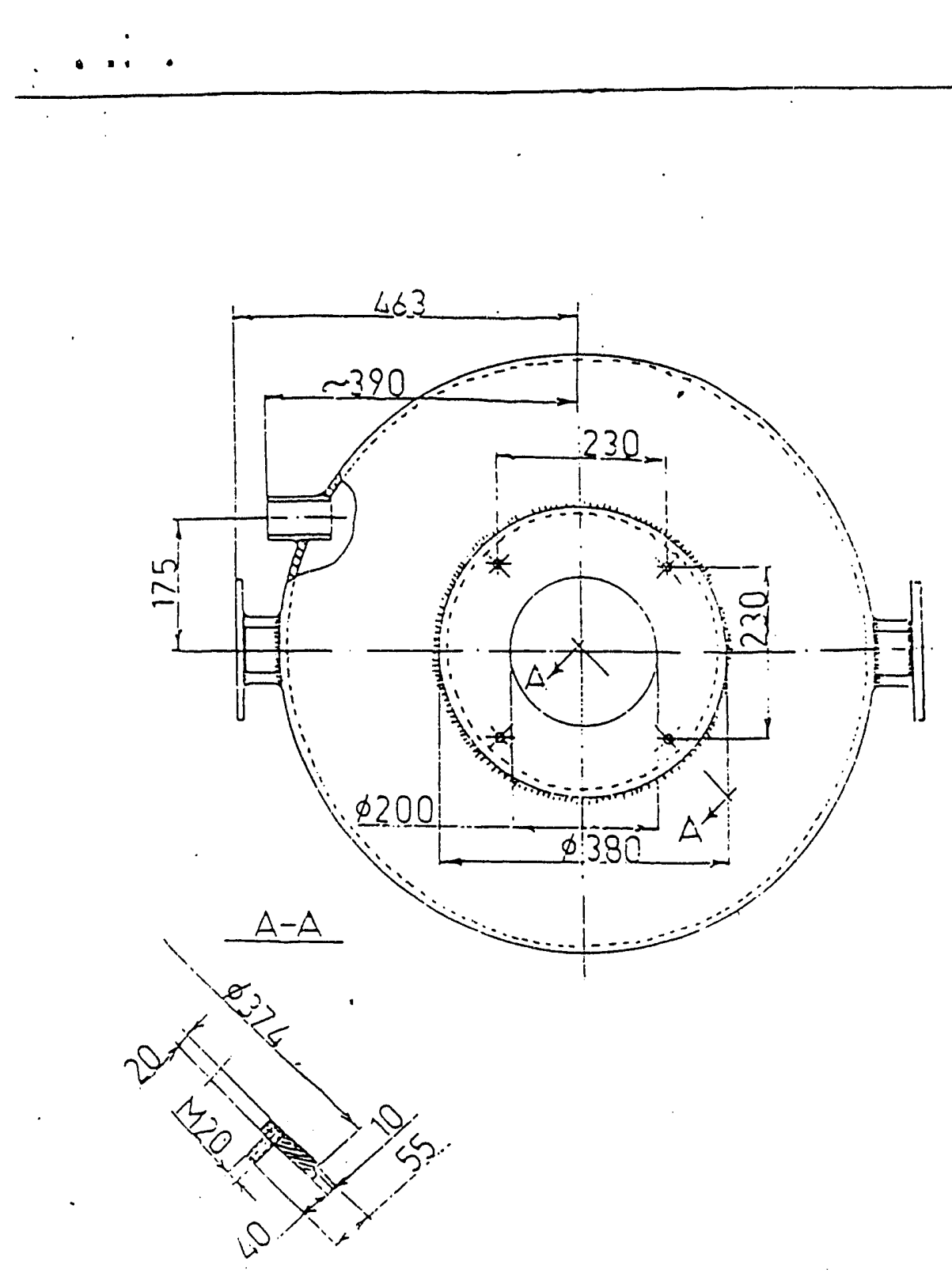





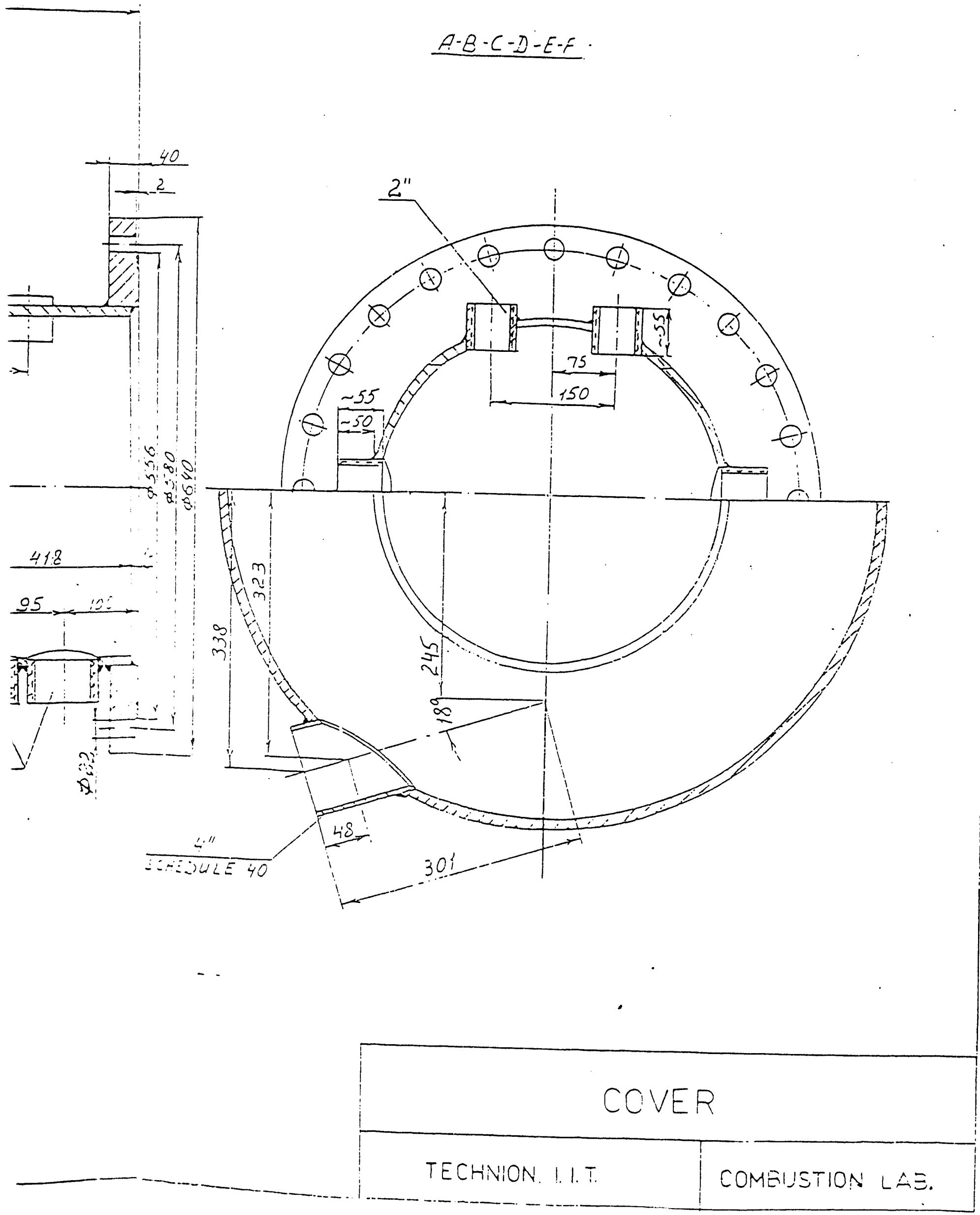




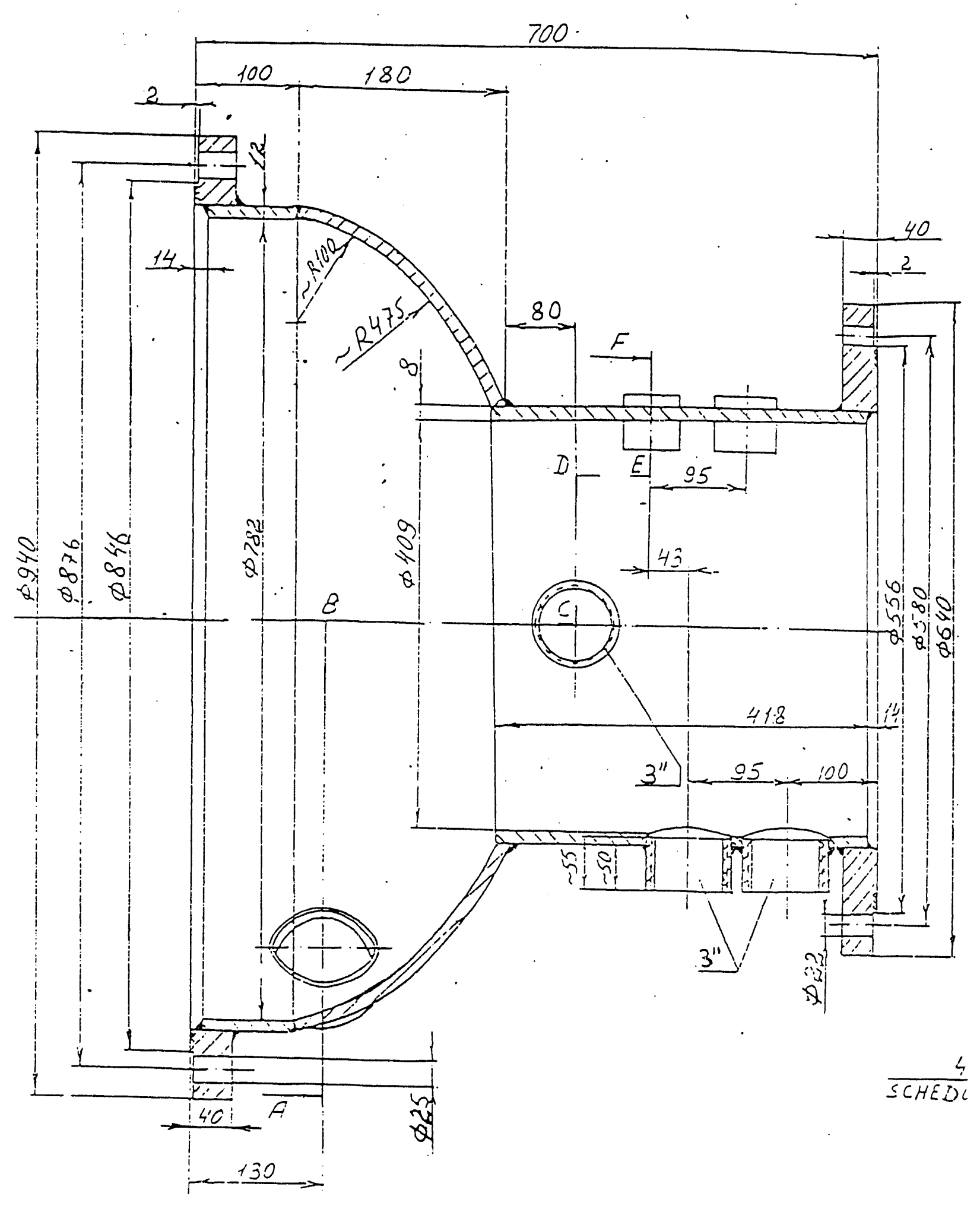




\section{(4)}
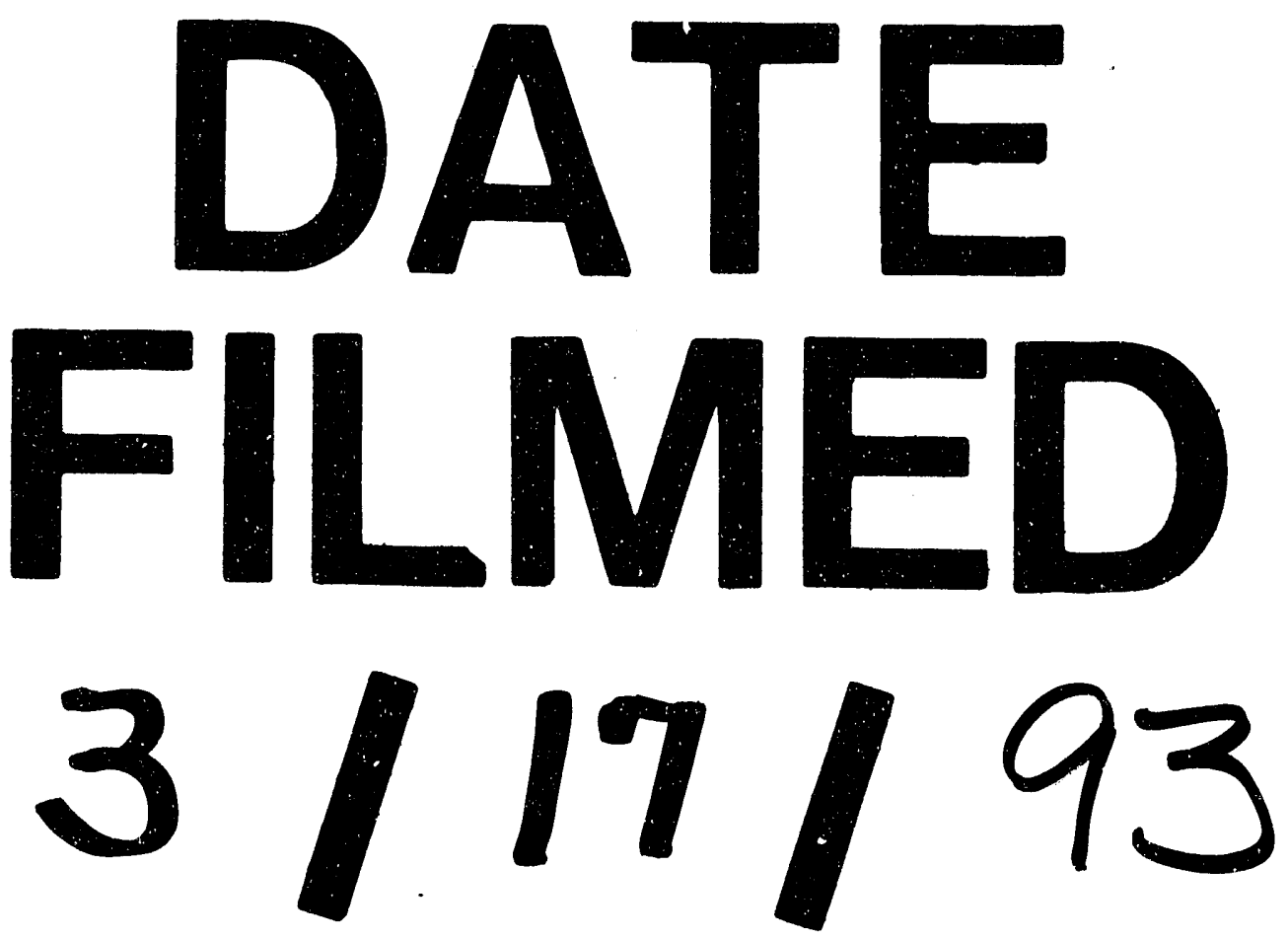
